\title{
Radical-scavenging and UV-radiation absorption activities of aaptamine derivatives: DFT and TD-DFT studies
}

\author{
Doan Thi Hoai Nam ${ }^{1}$, Thi Le Anh Nguyen ${ }^{2,3, *}$, Nguyen Thi Ai Nhung ${ }^{4}$, \\ Duong Tuan Quang ${ }^{5}$, Duy Quang Dao ${ }^{2}$ \\ ${ }^{I}$ Department of Chemistry, Danang University of Science and Technology - The University of Danang, Da \\ Nang, 550000, Vietnam \\ ${ }^{2}$ Institute of Research and Development, Duy Tan University, Da Nang, 550000, Vietnam \\ ${ }^{3}$ Faculty of Natural Sciences, Duy Tan University, Da Nang, 550000, Vietnam \\ ${ }^{4}$ Department of Chemistry, University of Sciences, Hue University, Hue city, 530000, Vietnam \\ ${ }^{5}$ Department of Chemistry, University of Education, Hue University, Hue city, 530000, Vietnam
}

Received: xxx; Accepted for Publication: xxx

\begin{abstract}
Antioxidant and UV absorption activities of three aaptamine derivatives including piperidine[3,2b]demethyl(oxy)aaptamine (C1), 9-amino-2-ethoxy-8-methoxy-3H-benzo[de][1,6]naphthyridine-3-one (C2), and 2(sec-butyl)-7,8-dimethoxybenzo[de]imidazo[4,5,1-ij][1,6]-naphthyridin-10(9H)-one $(\mathbf{C 3})$ were theoretically studied by density functional theory (DFT). Optimized geometries of $\mathbf{C 1}-\mathbf{C 3}$ and theirs intrinsic thermochemical properties such as bond dissociation energy, proton affinity, and ionization potential were calculated at DFT/M05-2X/6-311++G(d,p) level of theory in vacuo and in water. The results show that C1-C3 exhibited similar potent antioxidant activities, which are comparable to well-known antioxidants such as Trolox or cembrene. The radical scavenging activity of the antioxidants were then investigated by evaluation the Gibbs free energy $\left(\Delta_{\mathrm{r}} G^{0}\right)$ of the reaction between $\mathbf{C 1}-\mathbf{C} \mathbf{3}$ and the $\mathrm{HOO}^{\bullet} / \mathrm{HO}^{\bullet}$ radicals via four mechanisms, including: hydrogen atom transfer (HAT), single electron transfer (SET), proton loss (PL) and radical adduct formation (RAF). Kinetic calculation reveals that $\mathrm{HOO}^{\bullet}$ scavenging in water is occurred via HAT mechanism with C1@C19 while RAF is more dominant with C2 and C3. Antioxidant activity of aaptamine derivatives can be classified as $\mathbf{C 1}>\mathbf{C 3}>\mathbf{C 2}$. In addition, all compounds are active in UV-Vis absorption; the excitations of which are determined as $\pi-\pi^{*}$ transition. Overall, the results suggest the potential applications of the aaptamines in pharmaceutics and cosmetics, i.e. as sunscreen and antioxidant ingredient.
\end{abstract}

Keyword: Aaptamine, TD-DFT, antioxidant, free radical scavenging, UV-filter

\section{INTRODUCTION}

Aaptamines are commonly known marine natural products, which have been extracted from Aaptos aaptos species in the marine milieu of the Pacific ocean, i.e. Malaysia, ${ }^{1}$ Vietnam, ${ }^{2}$ and Indonesia. ${ }^{3}$ The first aaptamine structures, extracted from a Japanese sponge and characterized by Nakamura et al., ${ }^{4}$ are identified as alkaloid-based compounds containing the 1H-benzo[de]-1,6naphthyridine skeleton. To date, there is a large number of research which reported different biological activities of aaptamines such as antifungal, ${ }^{2} \quad{ }^{5}$ antiviral, ${ }^{6}$ antimicrobial, ${ }^{7}$ and anticancer. ${ }^{1} 38910$ In particular, antioxidant activity of aaptamines was early predicted and studied. Indeed, aaptamines and isoaaptamine, amongs other marine sponges, were reported for strong antioxidant activity against DPPH radical. ${ }^{11}$ In a perspective view, besides the natural and welldisposed origin, the antioxidant properties as well as other biological activities of the aaptamines can be of human-health-benefit because that helps protect our body from free radicals, fight aging, boosting the immune system, and prevent diseases.

On the other hand, oxidative stress (OS) resulting from long-time ultraviolet radiation (UVR) exposure is identified as one of the main causes for skin aging, DNA skin damage and melanogenesis. ${ }^{12}$ At the early stage of the sunscreen research started by the 1940s, most of the products targeted minimizing the effect of UVB (280-315 $\mathrm{nm})$ radiation because the direct UVB absorption by DNA generates UV-signature mutations leading to DNA lesions and carcinogenic effect. ${ }^{13}$ Scientists later discovered that the UVA $(315-400 \mathrm{~nm})$ can deeply penetrate into the skin, producing reactive oxygen species (ROS) and reactive nitrogen species (RNS) in human skin that cause DNA and other biological molecules to be damaged and so is not less harmful than the UVB to human skin. ${ }^{14}{ }^{15}$ One of the common mechanism, for example, is the ROS-mediated cell damage by peroxidation of fatty acids within the phospholipid structure of the membrane. Today, a broad-spectrum UV filter that covers both UVA and UVB is one of the most 
important properties for candidate compounds potentially applied in organic sunscreen. ${ }^{16}$

Moreover, the photo-protective properties of natural products have been earlier reported for natural antioxidants including polyphenols, ${ }^{17}$ stilbenes, ${ }^{18}$ hydroxycinamate derivatives. ${ }^{19}{ }^{20}$ A large number of studies have shown positive effect of antioxidant in the skin, for both treatment and prevention of inflammation, oxidation, sebaceous glands or melanogenesis. ${ }^{21}$ Multiple mechanisms of skin photo-protective have also been documented. ${ }^{15}$ In addition, the synthesis of p-hydroxycinnamic diacids such as of ferulic, sinapic, p-coumaric and caffeic diacid, the resulting molecules show potent antioxidant and UV filter. ${ }^{22}$ Recently, we reported the antioxidant and photo-protective properties of different natural compounds in which the cycloechinulin and wasabidienone extracted from marine fungus showed the most potential antioxidant and photo-protective properties. ${ }^{23}$ To the best of our knowledge, there have not been any studies that consider both the radical scavenging and photo-protective properties of the aaptamine derivatives.
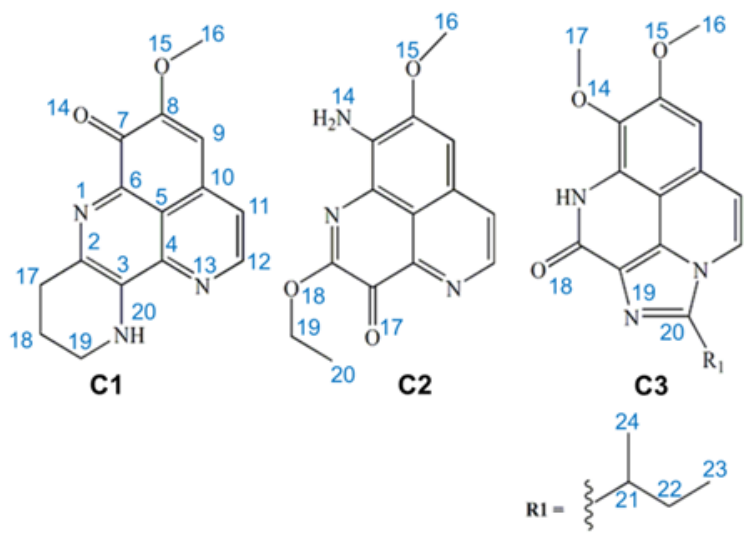

Figure 1. Chemical structure of C1-C3.

In this study, the antioxidant properties through free radical scavenging activity and the UV filter properties of three different aaptamine derivatives including piperidine[3,2-b]demethyl(oxy)aaptamine (C1), 9-amino-2-ethoxy-8-methoxy-3Hbenzo[de][1,6]naphthyridine-3-one (C2), and 2(sec-butyl)-7,8-dimethoxybenzo[de]imidazo[4,5,1ij][1,6]-naphthyridin-10(9H)-one $(\mathbf{C 3})$ reported by Nakamura et al. (Figure 1) were elucidated using density functional theory (DFT). Thermodynamic parameters of reaction characterized the antioxidant activity of three aaptamines C1-C3 via four common mechanisms: hydrogen atom transfer (HAT), single electron transfer (SET), proton loss (PL), and radical adduct formation (RAF) were focused. Different intrinsic thermochemical parameters including bond dissociation enthalpy (BDE), adiabatic ionization potential (IP) and proton affinity (PA) were calculated at the gas phase (vасио) and water. The reaction enthalpies $\left(\Delta_{\mathrm{r}} H^{0}\right)$ and standard Gibb free energies $\left(\Delta_{\mathrm{r}} G^{0}\right)$ of four reactions between the studied compounds and $\mathrm{HOO}^{\bullet}, \mathrm{OH}^{\bullet}$ radicals were also examined to elucidate their scavenging capabilities. Finally, the time-dependent density functional theory (TD-DFT) was used to elucidate the UV-Vis absorption mechanism of the three aaptamines.

\section{COMPUTATIONAL METHOD}

Gaussian 16 revision A.03 package was used to optimize the geometrical and electronic structures of the studied compounds. ${ }^{24}$ All calculations were performed at the DFT/M05-2X/6-311++G(d,p) level of theory. ${ }^{25}$ The M05-2X is previously reported to have a good benefit for the TS location and kinetics calculation. ${ }^{26} 27$

The four main working mechanisms, including hydrogen atom transfer (HAT), single electron transfer (SET), proton loss (PL) and radical adduct formation (RAF) have been investigated.

In the first approach, the intrinsic thermochemical parameters characterizing for three mechanisms HAT, SET, and PL were calculated according to the following reaction equations:

+ Hydrogen atom transfer (HAT):

$$
\begin{aligned}
& \mathrm{A}-\mathrm{H} \rightarrow \mathrm{A}^{\bullet}+\mathrm{H}^{\bullet} \quad(\mathrm{BDE}) ; \\
& + \text { Single electron transfer (SET): } \\
& \mathrm{A}-\mathrm{H} \rightarrow \mathrm{AH}^{\bullet}+\mathrm{e}^{-}(\mathrm{IP}) ; \\
& + \text { Proton transfer }(\mathrm{PT}) \text { : }
\end{aligned}
$$$$
\mathrm{A}-\mathrm{H} \rightarrow \mathrm{A}^{-}+\mathrm{H}^{+} \quad(\mathrm{PA}) \text {; }
$$

Based on the equations R1-R3, intrinsic thermodynamic parameters such as bond dissociation enthalpies (BDE), adiabatic ionization potential (IP), and proton affinities (PA) were calculated as follows:

$$
\begin{aligned}
& \operatorname{BDE}(\mathrm{A}-\mathrm{H})=H\left(\mathrm{~A}^{\bullet}\right)+H\left(\mathrm{H}^{\bullet}\right)-H(\mathrm{~A}-\mathrm{H}) ;(\text { eq.1) } \\
& \mathrm{IP}(\mathrm{A}-\mathrm{H})=H\left(\mathrm{AH}^{\bullet+}\right)+H\left(\mathrm{e}^{-}\right)-H(\mathrm{~A}-\mathrm{H}) ;(\text { eq. } 2) \\
& \mathrm{PA}(\mathrm{A}-\mathrm{H})=H\left(\mathrm{~A}^{-}\right)+H\left(\mathrm{H}^{+}\right)-H(\mathrm{~A}-\mathrm{H}) ;
\end{aligned}
$$

in which, $H$ accounts for the total energy of the studied species at $298.15 \mathrm{~K}$ and $1 \mathrm{~atm}$. The experimental energy value of the proton $\left(\mathrm{H}^{+}\right)$and the electron $\left(\mathrm{e}^{-}\right)$in gas phase was 1.4811 and 0.7519 kcal.mol ${ }^{-1}$, respectively. ${ }^{28}$ In water, the energy values of the proton $H\left(\mathrm{H}^{+}\right)$and of electron $H\left(\mathrm{e}^{-}\right)$were -235.3 and $-23.9 \mathrm{kcal}^{\mathrm{mol}}{ }^{-1}$, respectively; calculation method was previously reported. ${ }^{29}$

In order to evaluate the influence of chemical nature of free radicals on the antioxidant potential of the studied compounds $v s$. representative radicals such as $\mathrm{HOO}^{\circ}$, the standard Gibbs free energies of the reaction $\left(\Delta_{\mathrm{r}} G^{0}\right)$ were calculated for HAT, PL, RAF and SET mechanisms according to the R4-R7 reactions (eq.4-eq.7). Similar results for the $\mathrm{HO}^{\bullet}$ radical scavenging reactions were obtained in 
replacing the corresponding values of $\mathrm{HOO}^{\bullet}$ by that of $\mathrm{HO}^{\bullet}$ radical.

$$
\begin{aligned}
& \text { HAT: } \mathrm{A}-\mathrm{H}+\mathrm{HOO}^{\bullet} \rightarrow \mathrm{A}^{\bullet}+\mathrm{HOOH} \\
& \text { PL: } \mathrm{A}-\mathrm{H}+\mathrm{HOO}^{\bullet} \rightarrow \mathrm{A}^{-}+\mathrm{HOOH}^{\bullet+} \\
& \text { RAF: } \mathrm{A}-\mathrm{H}+\mathrm{HOO}^{\bullet} \rightarrow \mathrm{AH}-\mathrm{OOH}^{\bullet}
\end{aligned}
$$

SET: $\mathrm{A}-\mathrm{H}+\mathrm{HOO}^{\bullet} \rightarrow \mathrm{AH}^{\bullet+}+\mathrm{HOO}^{-}$;

Standard Gibbs free energies $\left(\Delta_{\mathrm{r}} G^{0}\right)$ of the reactions were calculated as follows:

$\Delta_{\mathrm{r}} G^{0}(\mathrm{HAT})=\left[G\left(\mathrm{~A}^{\bullet}\right)+G(\mathrm{HOOH})\right]-[G(\mathrm{~A}-\mathrm{H})+$ $\left.G\left(\mathrm{HOO}^{\circ}\right)\right] ;$ (eq.4)

$\Delta_{\mathrm{r}} G^{0}(\mathrm{PL})=\left[G\left(\mathrm{~A}^{-}\right)+G\left(\mathrm{HOOH}^{\bullet+}\right)\right]-[G(\mathrm{~A}-\mathrm{H})+$ $\left.G\left(\mathrm{HOO}^{\circ}\right)\right]$; (eq.5)

$\Delta_{\mathrm{r}} G^{0}(\mathrm{RAF})=G\left(\mathrm{AH}-\mathrm{OOH}^{\bullet}\right)-G(\mathrm{~A}-\mathrm{H})-$ $G\left(\mathrm{HOO}^{\bullet}\right)$; (eq.6)

$\Delta_{\mathrm{r}} G^{0}(\mathrm{SET})=\left[G\left(\mathrm{AH}^{\bullet+}\right)+G\left(\mathrm{HOO}^{-}\right)\right]-\left[G\left(\mathrm{HOO}^{\bullet}\right)+\right.$ $G(\mathrm{~A}-\mathrm{H})]$; (eq.7)

The kinetics of HT and RAF reactions in the gas phase and the water were studied in this work based on quantum mechanics-based test for overall free radical scavenging activity (QM-ORSA) protocol $^{26}$ using the Eyringpy code. ${ }^{30}$ Details of this calculation can be found in our previous work. ${ }^{23}$

$$
k(T)=\sigma \kappa \frac{k_{B} T}{h} e^{\frac{-\Delta G^{\ddagger}}{R T}}
$$

Where $\Delta \mathrm{G}^{*}$ is the Gibbs free energy of activation; $T$ is the temperature in Kelvin; $k_{\mathrm{B}}$ is the Boltzmann constant and $h$ is the Planck constant; $\sigma$ is the reaction symmetry number (or the reaction path degeneracy), $\kappa$ is the transmission coefficient attributing for the quantum tunneling effects by employing Eckart barrier. The solvent cage effect was included according to the correction proposed by Okuno, ${ }^{31}$ taking into account the free volume theory. ${ }^{32}$

For SET reaction, the Marcus theory ${ }^{33}$ was applied for the estimation of the electron transfer rate. The energy barrier was obtained as eq. 9 .

$$
\Delta G_{S E T}^{\ddagger}=\frac{\lambda}{4}\left(1+\frac{\Delta G_{S E T}^{0}}{\lambda}\right)^{2} \quad \text { (eq.9) }
$$

Where $\Delta G_{\text {SET }}^{0}$ is the free energy of reaction; $\lambda$ is the nuclear reorganization energy which can be calculated by the difference of $\Delta E_{\mathrm{SET}}$ and $\Delta E_{\mathrm{SET}}^{0}$, with $\Delta E_{\mathrm{SET}}$ is the vertical energy between reactants and products of the reaction via SET mechanism.

In solvent, diffusion rate $k_{\mathrm{D}}$ may be important and greatly contributes to the apparent rate constant $k_{\text {app. }}$. Therefore, the Collins-Kimball theory ${ }^{34}$ was employed (eq.10).

$$
k_{\mathrm{app}}=k_{\mathrm{D}} \cdot k /\left(k_{\mathrm{D}}+k\right)
$$

Where $k$ is the thermal rate constant and $k_{\mathrm{D}}$ is the diffusion rate constant calculated follow Smoluchowski ${ }^{35}$ (eq.11).

$k_{\mathrm{D}}=4 \pi R_{\mathrm{AB}} D_{\mathrm{AB}} N_{\mathrm{A}} \quad$ (eq.11)

where the $R_{\mathrm{AB}}$ is the reactant distance, $D_{\mathrm{AB}}$ is the mutual diffusion coefficient of the antioxidant $\mathrm{A}$ and radical $\mathrm{B}\left(\mathrm{HOO}^{\circ}\right) ; D_{\mathrm{AB}}$ is resulting from the Stockes-Einstein approach ${ }^{36}$ (eq.12)
$\mathrm{D}_{\mathrm{AB}}=k_{\mathrm{B}} \cdot \mathrm{T} /(6 \pi \eta \mathrm{r})$
(eq.12)

In which $k_{\mathrm{B}}$ is the Boltzmann constant, $\mathrm{T}$ is temperature and $\eta$ is the viscosity of the solvent $\left(8.91 \times 10^{-4}\right.$ P.s $)$ and $r$ is the radius of the solute.

For the basidity of the aaptamines, the $\mathrm{pK}_{\mathrm{a}}$ calculation was performed following the thermodynamic cycle previously reported. ${ }^{37} 38$

$\mathrm{pK}_{\mathrm{a}}$ of the C1-C3 were determined as (eq.13)

$\mathrm{pK}_{\mathrm{a}}=\Delta \mathrm{G}_{\text {deprot,aq }}^{0} / \mathrm{RT} \ln (10) \quad$ (eq.13)

in which the $\Delta G_{\text {deprotaq }}^{0}$ is the solution-phase standard free energy of deprotonation which can be calculated by thermodynamic cycle.

The vertical excitation of C1-C3 in methanol was calculated using TD-DFT approach. A small benchmark of functionals with different exchange correlation XC part, i.e. B3LYP, B98, M06, PBE0, CAMB3LYP, and M05-2X were employed with the same basis set as the previous part. These functionals are chosen following the recommendation by Jacquemine et al. for low Mean signed Error (MSE) and Mean absolute Error (MAE) for singlet excited states. ${ }^{39}$ Solvent effects were implicitly studied using the Polarization Continuum Model (IEF-PCM). ${ }^{40}$

\section{RESULTS AND DISCUSSION}

\subsection{Structure and electronic properties}

The optimized structures and electronic properties of the three studied aaptamine compounds calculated by DFT method at M05$2 \mathrm{X} / 6-311++\mathrm{G}(\mathrm{d}, \mathrm{p})$ level of theory in the gas phase are shown in Figure 2.

As can be seen in Figure 2, compounds C1-C3 share the benzo[de] $[1,6]$ naphthyridine skeleton and similarly have $-\mathrm{OCH}_{3}$ group attached to $\mathrm{C} 8$ position. At $\mathrm{C} 7$, the substituent groups such as ketone $(=\mathrm{O})$, amine $\left(-\mathrm{NH}_{2}\right)$ and methoxy $\left(-\mathrm{OCH}_{3}\right)$ are attached to the $\mathrm{B}$ ring, in $\mathbf{C 1}, \mathbf{C 2}$ and $\mathbf{C 3}$, respectively. The main difference in the chemical nature of three compounds is the substituent groups found at the A ring, for $\mathbf{C 1}$ a $\mathrm{N}$-containing sixmembered cycle, for $\mathbf{C} 2$ the $=\mathrm{O}$ and $-\mathrm{OC}_{2} \mathrm{H}_{5}$ group, and for $\mathbf{C 3}$ a $\mathrm{N}$-containing five-membered cycle with 2-butyl derivative that is shared both $\mathrm{A}$ and $\mathrm{C}$ ring. Moreover, the electronic distribution on the frontier molecular orbitals such as the highest occupied molecular orbital (HOMO) and the lowest 
unoccupied molecular orbital (LUMO) shows that all the rings play a key role in electron-donating (HOMO distribution) and electron-accepting (LUMO distribution) reactions with free radicals. For all molecules, the electrostatic potential (ESP) maps display a negative region on the $\mathrm{C}=\mathrm{O}$ groups and the nearby carbons.

\subsection{Basidity}

The $\mathrm{pK}_{\mathrm{a}}$ of three aaptamines $\mathbf{C 1 - C 3}$ calculated at M05-2X/6-311++G(d,p) level of theory is presented in Table 1. Similar calculation for aniline at the same level of theory was performed for comparison; the obtained value of $\mathrm{pK}_{\mathrm{a}}$ is 31.1 for aniline, consistent with the experimental data, i.e. 30.6, reported in DMSO and 28 in water. ${ }^{41}{ }^{42}$ For our aaptamines, the result shows that $\mathrm{pK}_{\mathrm{a}}$ of $\mathbf{C 1 - C 3}$ are of about 22-23. Therefore, in the following calculation we can consider the neutral form of $\mathbf{C 1 -}$ C3 in water.

Table 1. $\mathrm{pK}_{\mathrm{a}}$ of C1-C3 calculated in water at the M05-2X/6-311++G(d,p) level of theory

\begin{tabular}{|l|l|l|l|l|}
\hline Cpd & C1 & C2 & C3 & Aniline \\
\hline pK $_{\mathbf{a}}$ & 22.79 & 23.57 & 22.42 & $31.11^{*}$ \\
\hline
\end{tabular}

*Exp. value of 30.6 in DMSO and 28 in water (Bordwell 1977, 1988)

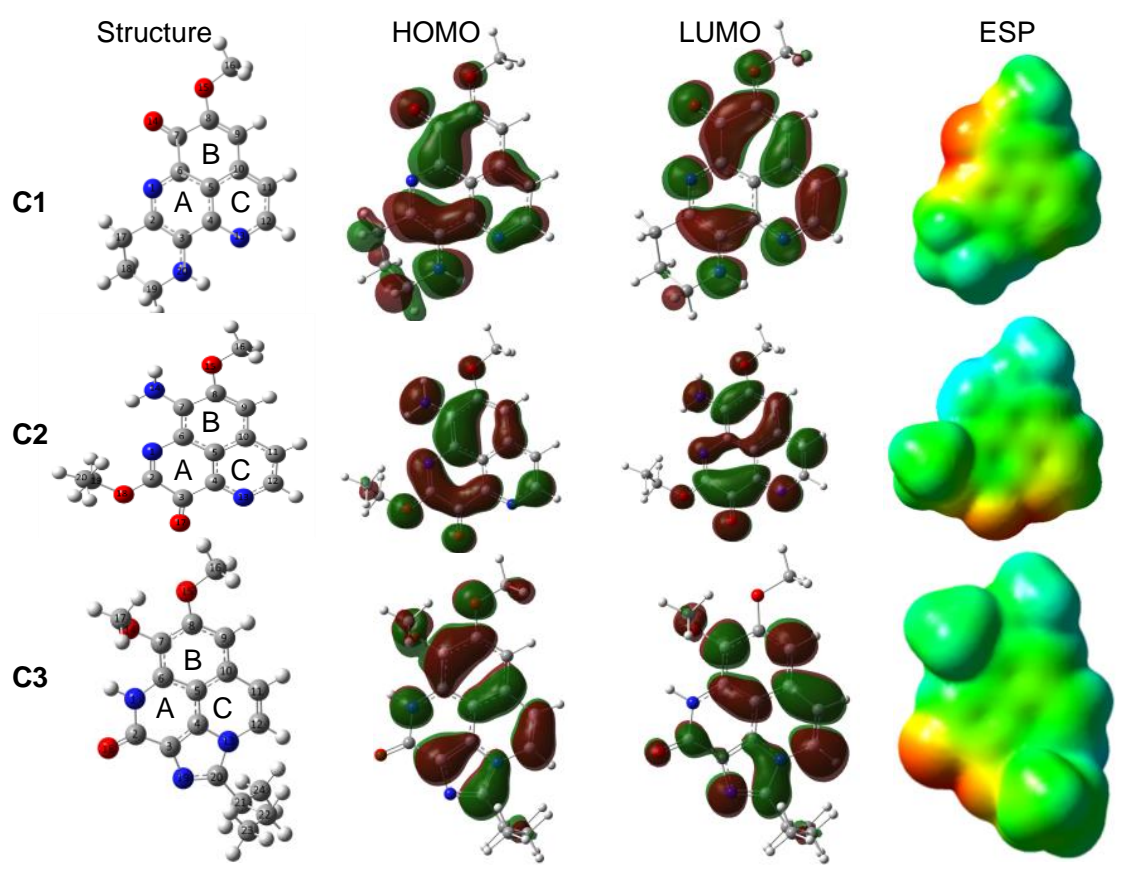

Figure 2. Optimized geometry, HOMO, LUMO, and ESP maps of C1-C3 calculated in the gas phase at the M05-2X/6-311++G(d,p) level of theory (isovalue $=0.02$ ).

\subsection{Evaluation of antioxidant potential via intrinsic thermochemical parameters}

Table 2 presented the intrinsic thermochemical parameters such as BDE, IP and PA which are examined via the HAT (R1), SET (R2) and PL (R3) mechanisms, respectively.

As can be seen in Table 2, the most favorable $\mathrm{H}$ donating positions for $\mathbf{C 1}$ and $\mathbf{C 3}$ are found at $\mathrm{C}-\mathrm{H}$ bonds. For example, the $\mathbf{C 1}$ exhibits the lowest BDE at $\mathrm{C} 17$ and $\mathrm{C} 19$ positions, being 85.5 and 85.7 kcal.mol ${ }^{-1}$, respectively, whereas $\mathbf{C 3}$ has the lowest $\mathrm{BDE}$ value at $\mathrm{C} 21$ position, i.e. $84.6 \mathrm{kcal}^{\mathrm{mol}}{ }^{-1}$. For C2, the easiest breaking-bond characterized by the lowest BDE value is located at N14 position (92.4 kcal.mol ${ }^{-1}$ ). It is noteworthy that BDE values of $\mathbf{C 1}$ and $\mathbf{C 3}$ are much lower than that of the standard antioxidant Trolox in the gas phase (i.e. 91.1 kcal.mol $\left.{ }^{-1}\right){ }^{43}$ Consequently, the antioxidant potential of these aaptamines via HAT process can be classified in the following order: C2 $<$ Trolox < C1 $<$ C3. We observed a very slight change of BDE values in water for all compounds C1-C3. The only exception is obtained for $\mathbf{C 1}$ at $\mathrm{C} 19$ position, with a $\mathrm{BDE}$ value in water lowering to $79.7 \mathrm{kcal}^{\mathrm{mol}}{ }^{-1} \mathrm{vs}$. $85.7 \mathrm{kcal}^{\mathrm{mol}}{ }^{-1}$ in gas phase. This result is not unexpected taken into account the neutral nature of the $\mathrm{H}$ atom species that is transferred.

The proton donating reaction from the aaptamines to free radical is characterized by the proton affinity (PA, eq.3); the lower the PA value, the better the antioxidant potential. As can be seen in Table 2, the lowest PA value of C1 is 342.5 $\mathrm{kcal}^{\mathrm{mol}}{ }^{-1}$ (at C20 position), that of C2 is 343.5 $\mathrm{kcal}^{\mathrm{mol}}{ }^{-1}$ (at N14 position) and the one of $\mathbf{C 3}$ being 
of $347.2 \mathrm{kcal}^{\mathrm{mol}}{ }^{-1}$ (at N1 position). These PA values are quite similar to that of cembrene in the gas phase (i.e. $\left.343.2 \mathrm{kcal} . \mathrm{mol}^{-1}\right)$. The proton donating ability of the three compounds in reaction with free radical according to the PL process is in the increasing order: $\mathbf{C 3}<$ cembrene $\approx \mathbf{C 2}<\mathbf{C 1}$. It is noteworthy that the PL is much preferred in water, for which the PA values are significantly reduced to a value of about $60 \mathrm{kcal}_{\mathrm{mol}}{ }^{-1}$. The result is totally in agreement with previous studies. ${ }^{44}$

Ionization potential (IP), characteristic for SET mechanism, is the minimum energy required to transfer an electron from the studied compound to free radical to form cationic species at ground state. The lower the IP value, the easier the electron transferring ability, thus, the antioxidant activity via SET mechanism will be higher. According to the results presented in Table 2, the adiabatic IP of
C1-C3 varied from 168 to $169 \mathrm{kcal}^{\mathrm{mol}}{ }^{-1}$, which is slightly higher than that of Trolox (i.e. 164.6 $\mathrm{kcal}^{\mathrm{mol}}{ }^{-1}$ ) and lower than the one of cembrene (i.e. $\left.171.9 \mathrm{kcal} . \mathrm{mol}^{-1}\right){ }^{43}$ The antioxidant activities of the studied aaptamines following the SET mechanism increases in the order: Trolox $<\mathbf{C 2}<\mathbf{C 1}<\mathbf{C 3}<$ cembrene. Similar to the proton transfer, the electron transfer is also favorable in water, with IP values reducing from $168-169 \mathrm{kcal}^{\mathrm{mol}}{ }^{-1}$ in gas phase to $109-114 \mathrm{kcal}^{\mathrm{mol}}{ }^{-1}$ in water, while remaining in the same order $\mathbf{C 2}<\mathbf{C 1}<\mathbf{C 3}$.

Overall, three aaptamines $\mathbf{C 1}-\mathbf{C} 3$ are potential antioxidants. In the gas phase, the HAT mechanism can be responsible for the antioxidant properties of the molecules while in water the PL mechanism is particularly favorable.

Table 2: BDE, PA and adiabatic IP values (in kcal.mol ${ }^{-1}$ ) of the $\mathbf{C 1 - C 3}$ calculated in the gas phase at the M05-2X/6-311++G(d,p) level of theory. Corresponding values in water are given in parentheses.

\begin{tabular}{|c|c|c|c|c|c|c|c|c|c|c|c|}
\hline \multicolumn{4}{|c|}{ C1 } & \multicolumn{4}{|c|}{ C2 } & \multicolumn{4}{|c|}{$\mathrm{C3}$} \\
\hline Pos & BDE & PA & IP & Pos & BDE & PA & IP & Pos & BDE & PA & IP \\
\hline C9 & 111.8 & 371.6 & \multirow{10}{*}{$\begin{array}{c}168.6 \\
(110.0)\end{array}$} & C9 & 113.9 & 366.7 & \multirow{10}{*}{\begin{tabular}{|c|}
168.3 \\
$(109.2)$
\end{tabular}} & C9 & 113.7 & 368.9 & \multirow{10}{*}{$\begin{array}{c}169.3 \\
(114.0)\end{array}$} \\
\hline $\mathrm{C} 11$ & 114.3 & \begin{tabular}{|l|}
374.4 \\
\end{tabular} & & C11 & 113.5 & 376.3 & & C11 & 114.9 & 371.3 & \\
\hline $\mathrm{C} 12$ & 106.2 & \begin{tabular}{|l}
383.6 \\
\end{tabular} & & C12 & 107.3 & 387.6 & & $\mathrm{C} 12$ & 114.4 & 360.6 & \\
\hline $\mathrm{C} 16$ & 97.1 & \begin{tabular}{|l|}
367.1 \\
\end{tabular} & & C16 & 97.6 & 384.4 & & C16 & 96.5 & 384.2 & \\
\hline $\mathrm{C} 17$ & $\begin{array}{c}85.5 \\
(85.6)\end{array}$ & \begin{tabular}{|l|}
366.4 \\
\end{tabular} & & C19 & 94.7 & 377.8 & & C17 & 97.3 & 389.3 & \\
\hline $\mathrm{C} 18$ & 98.9 & \begin{tabular}{|l|}
390.7 \\
\end{tabular} & & C20 & 100.8 & & & $\mathrm{C} 21$ & $\begin{array}{c}84.6 \\
(84.9)\end{array}$ & 366.3 & \\
\hline C19 & \begin{tabular}{|c|}
85.7 \\
$(79.7)$ \\
\end{tabular} & \begin{tabular}{|l|}
361.7 \\
\end{tabular} & & N14 & $\begin{array}{c}92.4 \\
(91.6)\end{array}$ & $\begin{array}{l}343.5 \\
(59.6)\end{array}$ & & $\mathrm{C} 22$ & 95.6 & 396.0 & \\
\hline \multirow[t]{3}{*}{$\mathrm{C} 20$} & 93.2 & $\begin{array}{l}342.5 \\
(60.2)\end{array}$ & & & & & & $\mathrm{C} 23$ & 99.8 & 360.7 & \\
\hline & & & & & & & & $\mathrm{C} 24$ & 99.0 & 390.4 & \\
\hline & & & & & & & & N1 & 101.8 & $\begin{array}{c}347.2 \\
(59.7)\end{array}$ & \\
\hline
\end{tabular}

\section{4. $\mathrm{HOO}^{\circ}$ and $\mathrm{HO}^{\circ}$ free radical scavenging}

The antioxidant potential of the studied aaptamines is investigated through the interactions with two representative free radicals, $\mathrm{HOO}^{\bullet}$ and $\mathrm{OH}^{\bullet}$ via four distinguished processes: hydrogen atom transfer (HAT), proton loss (PL), radical adduct formation (RAF), and single electron transfer (SET) mechanism (R4 - R7). The $\Delta_{\mathrm{r}} G^{0}$ of HAT, PL and RAF reactions between antioxidant and $\mathrm{HOO}^{\circ}$ and $\mathrm{HO}^{\circ}$ radicals are shown in Table 3 and Table 4, respectively. The reaction via SET mechanism is separately presented in Table 5 .

As shown in the Table 3, in the gas phase, the Gibbs free energy values $\left(\Delta_{\mathrm{r}} G^{0}\right)$ for HAT reaction (R4) towards $\mathrm{HOO}^{\bullet}$ are positive at all $\mathrm{H}$-donating positions, ranging from 0.2 to $30.5 \mathrm{kcal}^{\mathrm{mol}}{ }^{-1}$. This result indicates that the potential for $\mathrm{HOO}^{\bullet}$ removal via HAT mechanism of all three investigated compounds is not spontaneous and not favorable. Similarly, the proton transferring process (PL, R5) has positive $\Delta_{\mathrm{r}} G^{0}$ at all of the positions; thus, the ability to remove $\mathrm{HOO}^{\bullet}$ free radicals by PL process also is not favored in the gas phase. Concerning the RAF mechanism (R6), the $\Delta_{\mathrm{r}} G^{0}$ found negative values at some specific positions. For example, the C1 compound possesses highly negative $\Delta_{\mathrm{r}} G^{0}$ of 13.0 and $-12.6 \mathrm{kcal}^{\mathrm{mol}}{ }^{-1}$ at $\mathrm{C} 7$ and $\mathrm{C} 8$ positions, respectively. For $\mathbf{C 2}, \mathrm{HOO}^{\circ} \mathrm{RAF}$ process is highly negative at $\mathrm{C} 2$ position with $\Delta_{\mathrm{r}} G^{0}$ being -9.8 kcal.mol ${ }^{-1}$. Finally, for $\mathbf{C 3}$, the RAF reaction favorably occurs at $\mathrm{C} 2$ and $\mathrm{C} 12$ positions with $\Delta_{\mathrm{r}} G^{0}$ 
value being -14.2 and $-11.7 \mathrm{kcal}^{\mathrm{mol}} \mathrm{l}^{-1}$, respectively. Thus, for the scavenging process towards $\mathrm{HOO}^{\bullet}$ radical in the gas phase, the RAF is the only responsible mechanism. However, in water, $\mathrm{HOO}^{\bullet}$ scavenging happened neither with the PL nor with the RAF mechanism; all the Gibbs free energies
$\Delta_{\mathrm{r}} G^{0}$ are obtained positive. Only with HAT mechanism, there are two positions, i.e. $\mathrm{C} 19$ of $\mathbf{C 1}$ $\left(-0.5 \mathrm{kcal} . \mathrm{mol}^{-1}\right)$ and $\mathrm{C} 21$ of $\mathbf{C 3}\left(-0.4 \mathrm{kcal} . \mathrm{mol}^{-1}\right)$ give a spontaneous $\Delta_{\mathrm{r}} G^{0}$.

Table 3: Gibbs free energy $\left(\Delta_{\mathrm{r}} G^{0}, \mathrm{kcal}_{\mathrm{mol}}{ }^{-1}\right)$ of the HAT, PL, and RAF reaction of C1-C3 towards HOO radical in the gas phase. Corresponding values calculated in water are given in parentheses for the most spontaneous reactions only. All calculation are performed at the M05-2X/6-311++G(d,p) level of theory.

\begin{tabular}{|c|c|c|c|c|c|c|c|c|c|c|c|}
\hline \multicolumn{4}{|c|}{ HAT } & \multicolumn{4}{|c|}{ PL } & \multicolumn{4}{|c|}{ RAF } \\
\hline Pos. & C1 & $\mathrm{C2}$ & C3 & Pos. & C1 & C2 & $\mathrm{C3}$ & Pos. & C1 & $\mathrm{C2}$ & $\mathrm{C3}$ \\
\hline C9 & 27.3 & 29.5 & 29.2 & C9 & 219.8 & 214.9 & 217.0 & $\mathrm{C} 2$ & -1.0 & $\begin{array}{c}-9.8 \\
(5.2)\end{array}$ & - \\
\hline C11 & 29.8 & 29.0 & 30.5 & C11 & 222.5 & 224.5 & 219.4 & C3 & -7.8 & 10.3 & 7.9 \\
\hline C12 & 21.7 & 22.8 & 29.9 & C12 & 231.8 & 235.7 & 208.7 & $\mathrm{C} 4$ & 14.4 & 2.4 & 2.6 \\
\hline C16 & 12.7 & 13.1 & 12.0 & C16 & 224.3 & 232.5 & 232.3 & $\mathrm{C5}$ & 19.8 & 19.6 & 11.0 \\
\hline C17 & $\begin{array}{c}1.0 \\
(0.4)\end{array}$ & & 12.8 & C17 & 214.5 & & 237.5 & C6 & -3.6 & 0.1 & 9.6 \\
\hline C18 & 14.4 & & & C18 & 238.9 & & & C7 & - & -5.6 & -7.4 \\
\hline C19 & $\begin{array}{c}1.2 \\
(-5.0) \\
\end{array}$ & $\begin{array}{l}10.2 \\
(9.1)\end{array}$ & & C19 & 209.9 & 225.9 & & C8 & $\begin{array}{c}-12.6 \\
6.5\end{array}$ & -1.5 & 3.7 \\
\hline $\mathrm{C} 20$ & 8.7 & 16.4 & & $\mathrm{C} 20$ & $\begin{array}{l}190.6 \\
(77.3)\end{array}$ & & & C9 & -6.1 & 7.0 & -0.3 \\
\hline N14 & & $\begin{array}{c}7.9 \\
(7.1)\end{array}$ & & N14 & & $\begin{array}{l}191.7 \\
(77.5)\end{array}$ & & C10 & 8.3 & 16.5 & 9.8 \\
\hline N1 & & & 17.4 & N1 & & & $\begin{array}{c}195.3 \\
(76.8)\end{array}$ & C11 & -4.0 & -4.3 & -1.4 \\
\hline $\mathrm{C} 21$ & & & $\begin{array}{c}0.2 \\
(-0.4)\end{array}$ & $\mathrm{C} 21$ & & & 214.4 & C12 & 0.4 & 3.4 & $\begin{array}{r}-11.7 \\
(3.0)\end{array}$ \\
\hline $\mathrm{C} 22$ & & & 11.1 & $\mathrm{C} 22$ & & & 244.1 & & & & \\
\hline $\mathrm{C} 23$ & & & 15.4 & $\mathrm{C} 23$ & & & 208.9 & & & & \\
\hline $\mathrm{C} 24$ & & & 14.5 & C24 & & & 239.0 & & & & \\
\hline
\end{tabular}

Regarding to the $\mathrm{OH}^{\bullet}$ scavenging activities (Table 3), the negative $\Delta_{\mathrm{r}} G^{0}$ values are obtained at all positions of three studied compounds for both the HAT and RAF processes. This proves that C1-C3 have high scavenging potential towards $\mathrm{OH}^{\bullet}$ radical via HAT and RAF processes. The most active compound via HAT mechanism is awarded for $\mathbf{C 1}$ (C17 position) and $\mathbf{C 3}$ (C21 position), with the $\Delta_{\mathrm{r}} G^{0}$ of -30.7 and $-31.6 \mathrm{kcal}^{\mathrm{mol}}{ }^{-1}$, respectively. The lowest $\Delta_{\mathrm{r}} G^{0}$ values for RAF mechanism are obtained for $\mathbf{C} 1$ (C8 position) and $\mathbf{C 2}$ (C2 position) compounds with the values in the gas phase of -41.6 and $-39.3 \mathrm{kcal}^{\mathrm{mol}}{ }^{-1}$, respectively. For the proton transfer process, the positive value of $\Delta_{\mathrm{r}} G^{0}$ is observed at all the positions for all aaptamines. This result is reasonable because the gas phase is not a favorable medium for the charge transferring process like the proton transfer. In general, the RAF towards $\mathrm{OH}^{\bullet}$ is more favorable than the HAT and PL. For example, C1 has the lowest $\Delta_{\mathrm{r}} G^{0}(\mathrm{HAT})$ being $-30.7 \mathrm{kcal}^{\mathrm{mol}}{ }^{-1}$, whereas it has the lowest $\Delta_{\mathrm{r}} G^{0}(\mathrm{RAF})$ being $-41.6 \mathrm{kcal}^{\mathrm{mol}}{ }^{-1}$ and $\Delta_{\mathrm{r}} G^{0}(\mathrm{PL})$ being $407.9 \mathrm{kcal}^{-\mathrm{mol}^{-1}}$. In contrast, in water, the HAT is more competitive than the RAF. For example, the lowest $\Delta_{\mathrm{r}} G^{0}$ (HAT) of $\mathbf{C} \mathbf{1}$ is lowered to $-38.9 \mathrm{kcal}_{\mathrm{mol}}{ }^{-1}$ at $\mathrm{C} 19$, while the lowest $\Delta_{\mathrm{r}} G^{0}(\mathrm{RAF})$ is obtained with $\mathbf{C} 3$ with $-24.6 \mathrm{kcal}^{\mathrm{mol}}{ }^{-}$ ${ }^{1}$ at $\mathrm{C} 18$ position. On the other hand, the PL process is always not spontaneous and not favorable.

Moreover, as can be seen in the Table 5, Gibbs free energy of the SET reactions (R7) are not favorable in our conditions with the $\Delta_{\mathrm{r}} G^{0}$ value in the gas phase varying around $145 \mathrm{kcal}^{\mathrm{mol}}{ }^{-1}$ for

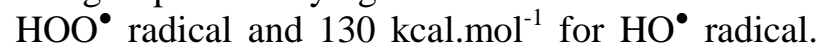
Although in water, the $\Delta_{\mathrm{r}} G^{0}$ have been significantly decreased $\left(15-41 \mathrm{kcal}^{\mathrm{mol}} \mathrm{l}^{-1}\right)$, the electron transfer is obviously not favorable. 
Table 4: Gibbs free energy $\left(\Delta_{\mathrm{r}} G^{0}, \mathrm{kcal}_{\mathrm{mol}}{ }^{-1}\right)$ of the HAT, PL, and RAF reaction of $\mathbf{C 1}-\mathbf{C 3}$ towards HO radical in the gas phase. Corresponding values calculated in water are only given (in parentheses) for the most spontaneous reactions. All calculation are performed at the M05-2X/6-311++G(d,p) level of theory.

\begin{tabular}{|c|c|c|c|c|c|c|c|c|c|c|c|}
\hline \multicolumn{4}{|c|}{ HAT } & \multicolumn{4}{|c|}{ PL } & \multicolumn{4}{|c|}{ RAF } \\
\hline Pos. & C1 & $\mathrm{C2}$ & $\mathrm{C3}$ & Pos. & C1 & $\mathrm{C2}$ & $\mathrm{C3}$ & Pos. & C1 & $\mathrm{C2}$ & $\mathrm{C3}$ \\
\hline C9 & -4.4 & -2.3 & -2.6 & C9 & 437.0 & 432.1 & 434.3 & $\mathrm{C} 2$ & & $\begin{array}{c}-39.3 \\
(-23.6)\end{array}$ & - \\
\hline $\mathrm{C} 11$ & -1.9 & -2.7 & -1.3 & C11 & 439.8 & 441.7 & 436.6 & C3 & -33.0 & -16.3 & -7.9 \\
\hline C12 & -10.0 & -8.9 & -1.9 & C12 & 449.0 & 453.0 & 425.9 & $\mathrm{C} 4$ & -9.8 & -21.7 & -10.4 \\
\hline $\mathrm{C} 16$ & -19.1 & -18.6 & -19.7 & $\mathrm{C} 16$ & 441.5 & 449.7 & 449.5 & $\mathrm{C} 5$ & -4.2 & -3.3 & -2.5 \\
\hline C17 & $\begin{array}{c}-30.7 \\
(-33.6) \\
\end{array}$ & & -18.9 & C17 & 431.8 & & 454.7 & C6 & -28.1 & -23.2 & -4.5 \\
\hline C18 & -17.3 & & & C18 & 456.1 & & & C7 & -17.8 & -32.1 & $\begin{array}{c}-26.7 \\
(-24.6)\end{array}$ \\
\hline C19 & $\begin{array}{c}-30.5 \\
(-38.9)\end{array}$ & $\begin{array}{c}-21.6 \\
(-24.8)\end{array}$ & & C19 & 427.1 & 443.1 & & C8 & $\begin{array}{c}-41.6 \\
(-21.6)\end{array}$ & -27.7 & -16.1 \\
\hline C20 & -23.0 & -15.4 & & $\mathrm{C} 20$ & $\begin{array}{l}407.9 \\
(79.7)\end{array}$ & & & C9 & -31.6 & -32.2 & -15 \\
\hline N14 & & $\begin{array}{c}-23.8 \\
(-26.8) \\
\end{array}$ & & N14 & & $\begin{array}{r}408.9 \\
(80.0) \\
\end{array}$ & & $\mathrm{C} 10$ & -15.0 & -5.7 & -2.1 \\
\hline N1 & & & -14.4 & N1 & & & $\begin{array}{l}412.5 \\
(79.2)\end{array}$ & $\mathrm{C} 11$ & -30.7 & -30.7 & -16.6 \\
\hline C21 & & & $\begin{array}{c}-31.6 \\
(-34.4) \\
\end{array}$ & $\mathrm{C} 21$ & & & 431.7 & $\mathrm{C} 12$ & -24.0 & -20.4 & $\begin{array}{c}-26.6 \\
(-24.2) \\
\end{array}$ \\
\hline C22 & & & -20.6 & C22 & & & 461.3 & & & & \\
\hline $\mathrm{C} 23$ & & & -16.4 & C23 & & & 426.1 & & & & \\
\hline C24 & & & -17.3 & $\mathrm{C} 24$ & & & 456.3 & & & & \\
\hline
\end{tabular}

Overall, the radical scavenging activities of the studied compounds favorably occur via RAF mechanism in the gas phase while in water it more likely occurs via HAT mechanism. The $\mathrm{HO}^{\bullet}$ radical scavenging is much more favorable than the reaction with $\mathrm{HOO}^{\circ}$. Finally, the antioxidant potential via HAT process of the three studied compounds is classified in the increasing trend: $\mathbf{C 2}<\mathbf{C 3} \approx \mathbf{C 1}$. For RAF mechanism, $\mathbf{C 1}$ and $\mathbf{C 2}$ are potent in gas phase while the $\mathbf{C 3}$ is more effective in water.

Table 5: Gibbs free energy $\left(\Delta_{\mathrm{r}} G^{0}, \mathrm{kcal}_{\mathrm{mol}}{ }^{-1}\right)$ of SET reaction towards $\mathrm{OOH}^{\bullet} / \mathrm{OH}^{\bullet}$ free radical

\begin{tabular}{|l|l|l|l|l|l|l|}
\hline \multirow{2}{*}{} & \multicolumn{2}{|c|}{$\mathbf{O O H}^{\bullet}$} & \multicolumn{2}{c|}{$\mathbf{O H}^{\bullet}$} \\
\cline { 2 - 7 } & C1 & C2 & C3 & C1 & C2 & C3 \\
\hline Gas & 145.1 & 144.8 & 145.5 & 129.7 & 129.5 & 130.2 \\
\hline Wat. & 37.4 & 37.2 & 41.1 & 15.3 & 15.2 & 19.0 \\
\hline
\end{tabular}

\subsection{Kinetics}

The kinetics of the possible reactions were studied with the neutral forms of C1-C3 in gas phase and water, for the $\mathrm{OOH}^{\bullet}$ scavenging. The Gibbs free energy of activation $\left(\Delta \mathrm{G}^{\ddagger}\right)$ and transition state theory (TST) rate constant $\left(k_{\mathrm{TST}}\right)$ for all reactions were systematically calculated in the gas phase and in water at the M05-2X/6-311++G(d,p) level of theory. Gibbs free energy of activation and TST rate constants obtained in the gas phase are presented in Table 6.

For HAT reaction, because C2 have all high positive Gibbs free energy of the reaction for all the $\mathrm{H}$ donating positions, we did not apply the kinetic calculation for this compound. Indeed, the compounds $\mathbf{C 1}$ and $\mathbf{C 3}$ display the activation Gibbs free energy of 16.8 and $19.8 \mathrm{kcal} / \mathrm{mol}$, respectively. Similar rate constants are also obtained for two compounds $\mathbf{C 1}$ and $\mathbf{C 3}\left(\sim 10^{-}\right.$ ${ }^{19} \mathrm{~cm}^{3} \cdot$ molecule $\left.{ }^{-1} \cdot \mathrm{s}^{-1}\right)$, which is much larger than the one of a standard antioxidant such as ascorbic acid $\left(\sim 10^{-15} \mathrm{~cm}^{3} \cdot\right.$ molecule $\left.{ }^{-1} \cdot \mathrm{s}^{-1}\right)$. For the RAF reaction, the lowest activation Gibbs free energy $(14.0 \mathrm{kcal} / \mathrm{mol})$ and the highest rate constant $(3.80$ $\times 10^{-18} \mathrm{~cm}^{3} \cdot$ molecule $\left.{ }^{-1} \cdot \mathrm{s}^{-1}\right)$ are obtained at the position $\mathrm{C} 2$ of aaptamine $\mathbf{C 2}$, indicate the most favorable reaction. At the second place, the $\mathbf{C 1}$ 
and ascorbic acid, are found with similar activation Gibbs free energy of about 14.8-15.0 $\mathrm{kcal} / \mathrm{mol}$ and rate constants of $3.4-3.6 \times 10^{-}$ ${ }^{19} \mathrm{~cm}^{3}$. molecule ${ }^{-1} \cdot \mathrm{s}^{-1}$. In contrary, the SET reaction is found with very high activation energy of about $400 \mathrm{kcal} / \mathrm{mol}$ and near-zero rate constants.

Table 6: Gibbs free energy of activation $\left(\Delta \mathrm{G}^{\ddagger}\right.$, in kcal.mol ${ }^{-1}$ ) at standard concentration $(1 \mathrm{M})$ and TST rate constant $\left(k_{\mathrm{TST}}\right.$, in $\mathrm{cm}^{3} \cdot$ molecule $\left.{ }^{-1} \cdot \mathrm{s}^{-1}\right)$ including the Eckart tunneling correction at 298.15 K calculated in the gas phase for HAT, RAF and SET reactions of C1-C3 towards HOO ${ }^{\circ}$ radical. Calculations are performed at the M05$2 \mathrm{X} / 6-311++\mathrm{G}(\mathrm{d}, \mathrm{p})$ level of theory.

\begin{tabular}{|c|c|c|}
\hline Reaction & $\begin{array}{c}\Delta \mathrm{G}^{\ddagger, 1 \mathrm{M}}, \\
\text { kcal.mol }^{-1}\end{array}$ & $\begin{array}{c}k_{\mathrm{TST}}^{, 298.15 \mathrm{~K}} \\
\mathrm{~cm}^{3} \cdot \text { molecule }^{-1} \cdot \mathrm{s} \\
1\end{array}$ \\
\hline \multicolumn{3}{|c|}{ HAT } \\
\hline C1@C19H + HOO• & 16.8 & $9.10 \times 10^{-19}$ \\
\hline C3@C21H + HOO• & 19.8 & $2.30 \times 10^{-19}$ \\
\hline Ascorbic + HOO• & 9.2 & $3.10 \times 10^{-15}$ \\
\hline \multicolumn{3}{|c|}{ RAF } \\
\hline C1@C8 + HOO• & 14.8 & $3.40 \times 10^{-19}$ \\
\hline $\mathbf{C 2} @ \mathrm{C} 2+\mathrm{HOO} \cdot$ & 14.0 & $3.80 \times 10^{-18}$ \\
\hline C3@C12 + HOO• & 15.6 & $7.60 \times 10^{-21}$ \\
\hline Ascorbic + HOO• & 15.0 & $3.60 \times 10^{-19}$ \\
\hline \multicolumn{3}{|c|}{ SET } \\
\hline $\mathbf{C 1}+\mathrm{HOO} \cdot$ & 420.9 & $4.30 \times 10^{-295}$ \\
\hline $\mathbf{C 2}+\mathrm{HOO} \cdot$ & 378.7 & $3.93 \times 10^{-264}$ \\
\hline $\mathbf{C 3}+\mathrm{HOO}$ & 401.3 & $1.05 \times 10^{-280}$ \\
\hline
\end{tabular}

For the reactions in water, kinetics data including the Gibbs free energy of activation $\Delta G^{\ddagger}$, the diffusion rate constants $k_{\mathrm{D}}$, thermal rate constant $k_{\mathrm{T}}$, Eckart-tunneling-corrected rate constants $k_{\text {eck, }}$ diffusion-corrected rate constants $\mathrm{k}_{\mathrm{app}}$, and the branching ratio $\Gamma$ for each reaction HAT, RAF and SET are resumed in Table 7.

For HAT reaction at the $\mathrm{C} 19 \mathrm{H}$ position of $\mathbf{C 1}$, it happens to be a barrierless reaction, with negative Gibbs free energy of activation $(-0.87 \mathrm{kcal} / \mathrm{mol})$. Moreover, the rate constant obtained at this position is of $7.13 \times 10^{6} \mathrm{M}^{-1} \mathrm{~s}^{-1}$. This is also the dominant reaction with for C1. In contrary, the C3 requires $5.17 \mathrm{kcal} / \mathrm{mol}$ of Gibbs free energy of activation and appears with a rate constant of only $3.84 \times 10^{3} \mathrm{M}^{-1} \mathrm{~s}^{-1}$. For RAF reaction, the reaction barriers $\left(\Delta \mathrm{G}^{\ddagger}\right)$ are found $5.6,7.2$ and $7.5 \mathrm{kcal} / \mathrm{mol}$ for $\mathbf{C 1}, \mathbf{C 2}, \mathbf{C 3}$, respectively. As can be seen in the Table 6, the diffusion rate constants $k_{\mathrm{D}}$ of RAF are dominant, with values of about $10^{9} \mathrm{M}^{-1} \mathrm{~s}$ ${ }^{1}$, while the thermal rate constants are much smaller $\left(\sim 10^{5} \mathrm{M}^{-1} \mathrm{~s}^{-1}\right)$. The fastest reaction is observed with $\mathbf{C 2}$ at the $\mathrm{C} 2$ position $\left(k_{\text {app }}=\right.$ $\left.1.40 \times 10^{5} \mathrm{M}^{-1} \mathrm{~s}^{-1}\right)$. Similar as in the gas phase, the SET reaction of all three compounds requires very high activation Gibbs free energy (45-53 $\mathrm{kcal} / \mathrm{mol}$ ) and occurred at extremely small rate $\left(10^{-25}-10^{-20} \mathrm{M}^{-1} \mathrm{~s}^{-1}\right)$. Overall, we observed a competition of the HAT and RAF reaction for the HOO• scavenging. For C1, the HAT reaction is dominant, while the $\mathrm{HOO} \cdot$ scavenging via $\mathrm{RAF}$ is more favored with $\mathbf{C 2}$ and $\mathbf{C 3}$.

Table 7: Gibbs free energy of activation $\left(\Delta \mathrm{G}^{\ddagger}, \mathrm{kcal} \mathrm{mol}^{-1}\right)$, diffusion rate constant $\left(k_{\mathrm{D}}, \mathrm{M}^{-1} \mathrm{~s}^{-1}\right)$, TST thermal rate constant $\left(k_{\mathrm{T}}, \mathrm{M}^{-1} \mathrm{~s}^{-1}\right)$, Eckart-tunneling-corrected rate constants $\left(k_{\text {eck }}, \mathrm{M}^{-1} \mathrm{~s}^{-1}\right)$ and diffusion-corrected apparent rate constants $\left(k_{\text {app }}, \mathrm{M}^{-1} \mathrm{~s}^{-1}\right)$ calculated at $298 \mathrm{~K}$ for the HAT, RAF and SET mechanism with HOO• radical in water.

\begin{tabular}{|c|c|c|c|c|c|c|}
\hline Reaction path & $\begin{array}{c}\Delta \mathrm{G}^{\ddagger, 1 \mathrm{M}}, \\
\text { kcal.mol }^{-1}\end{array}$ & $k_{\mathrm{D}}, \mathrm{M}^{-1} \mathrm{~s}^{-1}$ & $k_{\mathrm{T}}, \mathbf{M}^{-1} \mathbf{s}^{-1}$ & $k_{\text {eck }}, M^{-1} \mathbf{s}^{-1}$ & $k_{\text {app }}, \mathbf{M}^{-1} \mathrm{~s}^{-1}$ & $\Gamma, \%$ \\
\hline \multicolumn{7}{|c|}{ HAT } \\
\hline C1@C19H + HOO• & -0.87 & $1.40 \times 10^{9}$ & $7.17 \times 10^{6}$ & $3.22 \times 10^{-15}$ & $7.13 \times 10^{6}$ & 96 \\
\hline $\mathbf{C 3} @ \mathrm{C} 21 \mathrm{H}+\mathrm{HOO} \cdot$ & 5.17 & $1.27 \times 10^{9}$ & $3.84 \times 10^{3}$ & $3.22 \times 10^{-16}$ & $3.84 \times 10^{3}$ & 1 \\
\hline \multicolumn{7}{|c|}{ RAF } \\
\hline C1@C8 + HOO• & 7.2 & $2.10 \times 10^{9}$ & $3.00 \times 10^{7}$ & $2.80 \times 10^{5}$ & $2.80 \times 10^{5}$ & 4 \\
\hline $\mathbf{C 2} @ \mathrm{C} 2$ + $\mathrm{HOO} \cdot$ & 5.6 & $2.20 \times 10^{9}$ & $4.20 \times 10^{8}$ & $1.40 \times 10^{5}$ & $1.40 \times 10^{5}$ & 100 \\
\hline C3@C12 + HOO• & 7.5 & $2.00 \times 10^{9}$ & $1.90 \times 10^{7}$ & $2.90 \times 10^{5}$ & $2.90 \times 10^{5}$ & 99 \\
\hline \multicolumn{7}{|c|}{ SET } \\
\hline $\mathbf{C 1}+\mathrm{HOO} \bullet$ & 47.10 & $8.22 \times 10^{9}$ & $4.56 \times 10^{-21}$ & - & $4.56 \times 10^{-21}$ & 0 \\
\hline $\mathbf{C 2}+\mathrm{HOO} \bullet$ & 45.91 & $8.26 \times 10^{9}$ & $3.35 \times 10^{-20}$ & - & $3.35 \times 10^{-20}$ & 0 \\
\hline $\mathbf{C 3}+\mathrm{HOO} \bullet$ & 53.19 & $8.47 \times 10^{9}$ & $1.55 \times 10^{-25}$ & - & $1.55 \times 10^{-25}$ & 0 \\
\hline
\end{tabular}




\subsection{UV radiation absorption properties}

The vertical excitation of the molecules C1-C3 is studied with TD-DFT using different functionals such as B3LYP, B98, M06, PBE0, CAM-B3LYP and M05-2X as previously recommended for accuracy. ${ }^{39}$ In order to compare with experimental data reported in $\mathrm{MeOH}^{4}{ }^{4}$ all calculation is performed in $\mathrm{MeOH}$ using the implicit model IEF-PCM. The lowest absorption wavelength of each compound calculated by six above-mentioned functionals is presented in the Table 8 in comparison with the measured data.

As can be seen in Table 8, among the different methods, a fairly consistent result in comparison with the experimental data is obtained with CAMB3LYP and M05-2X functional. For example, the lowest absorption of $\mathbf{C 1}$ calculated in $\mathrm{MeOH}$ by M05-2X is found at $423 \mathrm{~nm}$ while the experimental value was reported at $398 \mathrm{~nm}$ in the same solvent ( $25 \mathrm{~nm}$ deviation). Similar deviation of about $30 \mathrm{~nm}$ was obtained for C2. However, a much higher deviation is observed with $\mathbf{C 3}$, for which a shorter wavelength of $292 \mathrm{~nm}$ is absorbed vs. $350 \mathrm{~nm}$ in measurement. The other methods, which comprise a portion of $20-30 \% \mathrm{HF}$ in exchange correlation give much less-comparative absorption. For example, the B3LYP functional (20\% HF) provides much higher absorption wavelengths, i.e. 471, 482 and $332 \mathrm{~nm}$ for C1-C3, respectively. As discussed in the literature, the main drawback of TD-DFT consists of the underestimation of the vertical excited energy, for which a significant error up to $0.4 \mathrm{eV}$ can be found. ${ }^{45}$ However, for comparative purpose, the TD-DFT results in general can still provide a benefit when it treats with the same kind of molecules.

Table 8. Lowest absorption wavelength $(\mathrm{nm})$ of C1-C3 calculated by TD-DFT with different methods of various \% $\mathrm{HF}$ in exchange correlation.

\begin{tabular}{|c|c|c|c|c|}
\hline \multirow{2}{*}{ Method } & \multirow{2}{*}{ \%HF } & \multicolumn{3}{|c|}{ Absorption / nm } \\
\cline { 3 - 5 } & & $\mathbf{C 1}$ & $\mathbf{C 2}$ & $\mathbf{C 3}$ \\
\hline B3LYP & 20 & 471 & 482 & 332 \\
\hline B98 & 22 & 465 & 476 & 327 \\
\hline M06 & 27 & 461 & 472 & 329 \\
\hline PBE0 & 25 & 459 & 470 & 322 \\
\hline CAM-B3LYP & $19 / 65$ & 427 & 439 & 298 \\
\hline M05-2X & 56 & 423 & 435 & 292 \\
\hline Exp. (ref.4) & & 398 & 402 & 350 \\
\hline
\end{tabular}

$19 \% \mathrm{HF}$ at short-range and $65 \% \mathrm{HF}$ at long-range

The vertical excited energy of some lowest excitations calculated by TD/M05-2X/6$311++\mathrm{G}(\mathrm{d}, \mathrm{p})$ as well as the oscillator strength and the nature of the corresponding electronic transition are presented in Table 9. Vertical excitations of $\mathbf{C 1}, \mathbf{C 2}$, and $\mathbf{C 3}$ is found at 2.93, 2.87 and $4.24 \mathrm{eV}$, respectively. In all cases, we observed mainly the contribution of the HOMO to LUMO transition for the lowest lying excitation of C1-C3. This contribution varies from $96 \%$ for $\mathbf{C 1}, 97 \%$ for $\mathbf{C 2}$ and $86 \%$ for $\mathbf{C 3}$. As predicted in the electronic properties part, the HOMO and LUMO of three compounds involved mostly the rings of aaptamine derivatives, then all the lowest absorption is characterized as $\pi-\pi^{*}$ transition.

Table 9. Vertical excited energies (eV), absorption wavelength (nm), oscillator strength $f$ and the corresponding electronic transition of some lowest excited states of C1-C3 calculated by TD-DFT at M05-2X/6-311++G(d,p) in $\mathrm{MeOH}$.

\begin{tabular}{|c|c|c|c|c|c|c|}
\hline Cp & ES & E/eV & A/nm & $f$ & Transition & $\%$ \\
\hline \multirow{5}{*}{ C1 } & S1 & 2.93 & 423 & 0.3553 & $\mathrm{H} \rightarrow \mathrm{L}$ & 96 \\
\hline & S3 & 3.60 & 345 & 0.1614 & $\mathrm{H}-1 \rightarrow \mathrm{L}$ & 91 \\
\hline & S7 & 4.84 & 257 & 0.4625 & $\begin{array}{l}\mathrm{H}-2 \rightarrow \mathrm{L} \\
\mathrm{H} \rightarrow \mathrm{L}+1\end{array}$ & $\begin{array}{l}47 \\
43\end{array}$ \\
\hline & S8 & 5.33 & 233 & 0.1603 & $\mathrm{H} \rightarrow \mathrm{L}+2$ & 92 \\
\hline & & 5.72 & 212 & 0.0277 & $\begin{array}{l}\mathrm{H}-1 \rightarrow \mathrm{L}+1 \\
\mathrm{H} \rightarrow \mathrm{L}+3\end{array}$ & $\begin{array}{l}62 \\
24\end{array}$ \\
\hline \multirow[t]{5}{*}{ C2 } & S1 & 2.87 & 435 & 0.2938 & $\mathrm{H} \rightarrow \mathrm{L}$ & 97 \\
\hline & S3 & 3.78 & 328 & 0.1196 & $\begin{array}{l}\mathrm{H}-1 \rightarrow \mathrm{L} \\
\mathrm{H}-3 \rightarrow \mathrm{L}\end{array}$ & $\begin{array}{l}86 \\
6\end{array}$ \\
\hline & S6 & 5.01 & 248 & 0.6778 & $\begin{array}{l}\mathrm{H} \rightarrow \mathrm{L}+1 \\
\mathrm{H}-1 \rightarrow \mathrm{L}\end{array}$ & $\begin{array}{l}77 \\
8 \\
8\end{array}$ \\
\hline & & & & & $\begin{array}{l}\mathrm{H}-3 \rightarrow \mathrm{L} \\
\mathrm{H} \rightarrow \mathrm{I}+2\end{array}$ & $\begin{array}{l}8 \\
83\end{array}$ \\
\hline & So & 5.24 & 201 & $0.1 / 34$ & $\begin{array}{l}\mathrm{H} \rightarrow \mathrm{L}+2 \\
\mathrm{H}-3 \rightarrow \mathrm{L}\end{array}$ & 8 \\
\hline \multirow[t]{11}{*}{$\mathrm{C3}$} & S1 & 4.24 & 292 & 0.1447 & $\begin{array}{l}\mathrm{H} \rightarrow \mathrm{L} \\
\mathrm{H}-1 \rightarrow \mathrm{L}+1\end{array}$ & $\begin{array}{l}86 \\
8\end{array}$ \\
\hline & S3 & 4.90 & 253 & 0.5688 & $\begin{array}{l}\mathrm{H} \rightarrow \mathrm{L}+1 \\
\mathrm{H} \rightarrow \mathrm{L}+2 \\
\mathrm{H}-1 \rightarrow \mathrm{L} \\
\mathrm{H}-1 \rightarrow \mathrm{L}+2\end{array}$ & $\begin{array}{l}45 \\
21 \\
15 \\
9\end{array}$ \\
\hline & S4 & 5.22 & 238 & 0.1517 & $\begin{array}{l}\mathrm{H}-1 \rightarrow \mathrm{L}+2 \\
\mathrm{H}-1 \rightarrow \mathrm{L} \\
\mathrm{H} \rightarrow \mathrm{L}+2 \\
\mathrm{H} \rightarrow \mathrm{L}+1\end{array}$ & $\begin{array}{l}72 \\
13 \\
6 \\
5\end{array}$ \\
\hline & S5 & 5.46 & 227 & 0.9586 & $\mathrm{H} \rightarrow \mathrm{L}+2$ & 55 \\
\hline & & & & & $\begin{array}{l}\mathrm{H}-1 \rightarrow \mathrm{L} \\
\mathrm{H}-1 \rightarrow \mathrm{L}+1\end{array}$ & $\begin{array}{l}15 \\
8\end{array}$ \\
\hline & & & & & $\mathrm{H}-1 \rightarrow \mathrm{L}+2$ & 8 \\
\hline & & & & & $\mathrm{H} \rightarrow \mathrm{L}+1$ & 7 \\
\hline & S7 & 5.71 & 217 & 0.2460 & $\mathrm{H}-1 \rightarrow \mathrm{L}+2$ & 49 \\
\hline & & & & & $\mathrm{H}-2 \rightarrow \mathrm{L}$ & 18 \\
\hline & & & & & $\mathrm{H} \rightarrow \mathrm{L}+2$ & 15 \\
\hline & & & & & $\mathrm{H} \rightarrow \mathrm{L}+6$ & 5 \\
\hline
\end{tabular}

Finally, the Figure 3 displayed the energy gap and energy level of the frontier molecular orbitals that participated to the lowest electronic transition of the C1-C3. One can easily notice that: $(i)$ there is a much lower gap $(4.9 \mathrm{eV})$ for $\mathbf{C 1}$ and $\mathbf{C 2}$ in comparison with $6.5 \mathrm{eV}$ gap in case of $\mathbf{C 3}$, and 
(ii) possessing the same energy level for HOMO, the energy level of LUMO of $\mathbf{C 1}$ and $\mathbf{C 2}$ is much lower than that of $\mathbf{C 3}$. All results indicate that the $\mathbf{C 1}$ and $\mathbf{C 2}$ can be easily excited within the visible (blue) and UV range while the $\mathbf{C 3}$ are effective UV absorption agent. The results suggest the use of aaptamines $\mathbf{C 1}-\mathbf{C} \mathbf{3}$ as photo-protective agents.

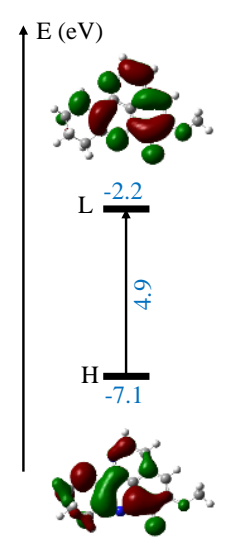

C1

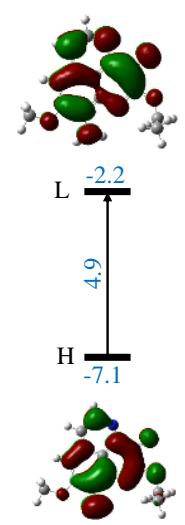

C2

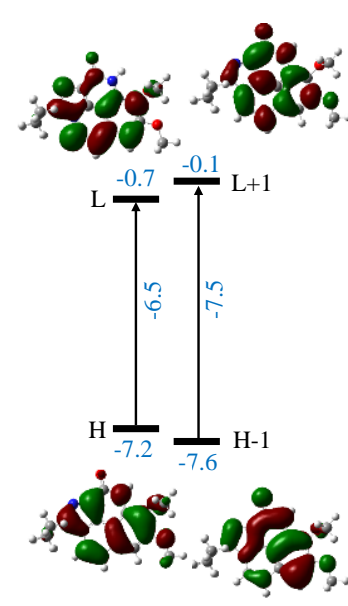

C3
Figure 3. The energy gap and energy levels of the frontier molecular orbitals which participated to the lowest electronic transition of C1-C3. The result is obtained with DFT/M05-2X/6$311++\mathrm{G}(\mathrm{d}, \mathrm{p})$ in $\mathrm{MeOH}$ (IEF-PCM).

\section{CONCLUSIONS}

The antioxidant activities of three aaptamines (C1, C2 and C3) extracted from sponges was investigated in the gas phase and water using DFT method according to four mechanisms: HAT, SET, PL and RAF. All of these investigated compounds exhibited the best antioxidant activity via RAF mechanism, for which antioxidant potential is classified in the increasing order $\mathbf{C 2}<$ $\mathbf{C 1}<\mathbf{C 3}$ for $\mathrm{HOO}^{\bullet}$ and $\mathbf{C 3}<\mathbf{C 2}<\mathbf{C 1}$ for $\mathrm{HO}^{\bullet}$ free radical scavenging activity. Furthermore, HAT mechanism is elucidated as the second competitive mechanism, in particularly for $\mathrm{HO}^{\bullet}$ quenching and in water. Thermodynamically, the antioxidant activities via four studied processes are in the decreasing order as follows: RAF > HAT $>$ SET $>$ PL (gas) and HAT $>$ RAF $>$ SET > PL (water). Kinetic calculation show that the HAT mechanism is the most favorable path for $\mathrm{HOO}^{\bullet}$ scavenging in water with $\mathbf{C 1}$ while the $\mathrm{RAF}$ is more competitive with $\mathbf{C 2}$ and $\mathbf{C 3}$. Second, all compounds, particularly the $\mathbf{C 3}$, are effective in the UV absorption. Within the range of our study, the M05-2X level provides the best performance for calculation of vertical excited energy using TD-DFT. These results promote aaptamine derivatives as natural antioxidant and
anti-UV agents for the use in human healthcare such as in pharmaceutics and cosmetics.

Acknowledgments. This research is funded by Vietnam National Foundation for Science and Technology Development (NAFOSTED) under grant number 103.01-2019.380. The authors are grateful for the help in kinetic calculation from Dr. Thi Chinh Ngo and Mr. Dinh Hieu Truong (Duy Tan University).

Conflict of interest. The authors declare no conflict of interest.

\section{REFERENCES}

1. Shaari, K.; Ling, K. C.; Rashid, Z. M.; Jean, T. P.; Abas, F.; Raof, S. M.; Zainal, Z.; Lajis, N. H.; Mohamad, H.; Ali, A. M., Cytotoxic Aaptamines from Malaysian Aaptos aaptos. Marine Drugs 2009, 7, 1-8.

2. Shubina, L. K.; Kalinovsky, A. I.; Fedorov, S. N.; Radchenko, O. S.; Denisenko, V. A.; Dmitrenok, P. S.; Dyshlovoy, S. A.; Krasokhin, V. B.; Stonik, V. A., Aaptamine Alkaloids from the Vietnamese Sponge Aaptos sp. Nat. Prod. Commun. 2009, 4 (8), 1085-1088.

3. Pham, C. D.; Hartmann, R.; Muller, W. E.; de Voogd, N.; Lai, D.; Proksch, P., Aaptamine derivatives from the Indonesian sponge Aaptos suberitoides. J. Nat. Prod. 2013, 76 (1), 103-106.

4. Nakamura, H.; Kobayashi, J.; Ohizumi, Y.; Hirata, Y., Isolation and structure of aaptamine a novel heteroaromatic substance possessing a-blocking activity from the sea sponge aaptos aaptos. Tetrahedron Letters 1982, 23 (52), 5555-5558.

5. Yu, H.-B.; Yang, F.; Sun, F.; Li, J.; Jiao, W.-H.; Gan, J.-H.; Hu, W.-Z.; Lin, H.-W., Aaptamine Derivatives with Antifungal and Anti-HIV-1

Activities from the South China Sea Sponge Aaptos aaptos. Marine Drugs 2014, 12, 60036013.

6. Bowling, J. J.; Pennaka, H. K.; Ivey, K.; Wahyuono, S.; Kelly, M.; Schinazi, R. F.; Valeriote, F. A.; Graves, D. E.; Hamann, M. T., Antiviral and anticancer optimization studies of the DNA-binding marine natural product aaptamine. Chem. Biol. Drug Des. 2008, 71 (3), 205-215. 
7. Rajivgandhi, G.; kumar, S. N.; Ramachandran, G.; Manoharan, N., Marine sponge alkaloid aaptamine enhances the antibacterial and anti-cancer activity against ESBL producing Gram negative bacteria and HepG 2 human liver carcinoma cells. Biocat. Agri. Biotech. 2019, 17, 628-637.

8. Yu, H. B.; Yang, F.; Sun, F.; Ma, G. Y.; Gan, J. H.; Hu, W. Z.; Han, B. N.; Jiao, W. H.; Lin, H. W., Cytotoxic aaptamine derivatives from the South China Sea sponge Aaptos aaptos. J. Nat. Prod. 2014, 77 (9), 2124-2129.

9. (a) Dyshlovoy, S. A.; Fedorov, S. N.; Shubina, L. K.; Kuzmich, A. S.; Bokemeyer, C.; Keller-von Amsberg, G.; Honecker, F., Aaptamines from the marine sponge Aaptos sp. display anticancer activities in human cancer cell lines and modulate AP-1-, NFkappaB-, and p53-dependent transcriptional activity in mouse JB6 Cl41 cells. Biomed. Res. Int. 2014, 2014, 469309; (b) Dyshlovoy, S. A.; Venz, S.; Shubina, L. K.; Fedorov, S. N.; Walther, R.; Jacobsen, C.; Stonik, V. A.; Bokemeyer, C.; Balabanov, S.; Honecker, F., Activity of aaptamine and two derivatives, demethyloxyaaptamine and isoaaptamine, in cisplatin-resistant germ cell cancer. $J$. Proteomics 2014, 96, 223-239.

10. Hamada, T.; Matsumoto, Y.; Phan, C.-S.; Kamada, T.; Onitsuka, S.; Okamura, H.; Iwagawa, T.; Arima, N.; Tani, F.; Vairappan, C. S., Aaptamine-Related Alkaloid from the Marine Sponge Aaptos aaptos. Nat. Prod. Commun. 2019, 14 (9), 1-3.

11. Takamatsu, S.; Hodges, T. W.; Rajbhandari, I.; Gerwick, W. H.; Hamann, M. T.; Nagle, D. G., Marine Natural Products as Novel Antioxidant Prototypes. J. Nat. Prod. 2003, 66, 605-608.

12. Krutmann, J.; Bouloc, A.; Sore, G.; Bernard, B. A.; Passeron, T., The skin aging exposome. J. Dermatol. Sci. 2017, 85 (3), 152-161.

13. Cadet, J.; Douki, T.; Ravanat, J. L.; Di Mascio, P., Sensitized formation of oxidatively generated damage to cellular DNA by UVA radiation. Photochem. Photobiol. Sci. 2009, 8 (7), 903-911.

14. Fourtanier, A.; Moyal, D.; Seite, S., UVA filters in sun-protection products: regulatory and biological aspects. Photochem. Photobiol. Sci. 2012, 11 (1), 81-89.

15. Dunaway, S.; Odin, R.; Zhou, L.; Ji, L.; Zhang, Y.; Kadekaro, A. L., Natural Antioxidants: Multiple Mechanisms to Protect Skin From Solar Radiation. Front. Pharmacol. 2018, 9, 392.

16. Latha, M. S.; Martis, J.; V, S.; Shinde, R. S.; Bangera, S.; Krishnankutty, B.; Bellary, S.; Varughese, S.; Rao, P.; Kumar, B. R. N., Sunscreening Agents: A review. J. Clin. Aesth. Dermatol. 2013, 6 (1), 16-26.

17. Stevanato, R.; Bertelle, M.; Fabris, S., Photoprotective characteristics of natural antioxidant polyphenols. Regul. Toxicol. Pharmacol. 2014, 69 (1), 71-77.

18. Freitas, J. V.; Praca, F. S.; Bentley, M. V.; Gaspar, L. R., Trans-resveratrol and betacarotene from sunscreens penetrate viable skin layers and reduce cutaneous penetration of UV-filters. Int. J. Pharm. 2015, 484 (1-2), 131-137.

19. Peres, D. D.; Sarruf, F. D.; de Oliveira, C. A.; Velasco, M. V. R.; Baby, A. R., Ferulic acid photoprotective properties in association with UV filters: multifunctional sunscreen with improved SPF and UVA-PF. $J$. Photochem. Photobiol. B 2018, 185, 46-49.

20. Scalia, S.; Mezzena, M., Photostabilization Effect of Quercetin on the UV Filter Combination, Butyl Methoxydibenzoylmethane-Octyl

Methoxycinnamate. Photochem. Photobiol. 2010, 86, 273-278.

21. Masaki, H., Role of antioxidants in the skin: anti-aging effects. J. Dermatol. Sci. 2010, 58 (2), 85-90.

22. Rioux, B.; Peyrot, C.; Mention, M. M.; Brunissen, F.; Allais, F., Sustainable Synthesis of p-Hydroxycinnamic Diacids through Proline-Mediated Knoevenagel Condensation in Ethanol: An Access to Potent Phenolic UV Filters and Radical Scavengers. Antioxidants 2020, 9 (4), 331.

23. Dao, D. Q.; Phan, T. T. T.; Nguyen, T. L. A.; Trinh, P. T. H.; Tran, T. T. V.; Lee, J. S.; Shin, H. J.; Choi, B. K., Insight into Antioxidant and Photoprotective Properties of Natural Compounds from Marine Fungus. $J$. Chem. Inf. Model. 2020, 60 (3), 1329-1351.

24. Gaussian 16, A., M. J. Frisch, G. W. Trucks, H. B. Schlegel, G. E. Scuseria, M. A. 
Robb, J. R. Cheeseman, G. Scalmani, V. Barone, G. A. Petersson, H. Nakatsuji, X. Li, M. Caricato, A. Marenich, J. Bloino, B. G. Janesko, R. Gomperts, B. Mennucci, H. P. Hratchian, J. V. Ortiz, A. F. Izmaylov, J. L. Sonnenberg, D. Williams-Young, F. Ding, F. Lipparini, F. Egidi, J. Goings, B. Peng, A. Petrone, T. Henderson, D. Ranasinghe, V. G. Zakrzewski, J. Gao, N. Rega, G. Zheng, W. Liang, M. Hada, M. Ehara, K. Toyota, R. Fukuda, J. Hasegawa, M. Ishida, T. Nakajima, Y. Honda, O. Kitao, H. Nakai, T. Vreven, K. Throssell, J. A. Montgomery, Jr., J. E. Peralta, F. Ogliaro, M. Bearpark, J. J. Heyd, E. Brothers, K. N. Kudin, V. N. Staroverov, T. Keith, R. Kobayashi, J. Normand, K. Raghavachari, A. Rendell, J. C. Burant, S. S. Iyengar, J. Tomasi, M. Cossi, J. M. Millam, M. Klene, C. Adamo, R. Cammi, J. W. Ochterski, R. L. Martin, K. Morokuma, O. Farkas, J. B. Foresman, and D. J. Fox, Gaussian, Inc., Wallingford CT, 2016.

25. Zhao, Y.; Schultz, N. E.; Truhlar, D. G., Design of Density Functionals by Combining the Method of Constraint Satisfaction with Parametrization for Thermochemistry, Thermochemical Kinetics, and Noncovalent Interactions. J. Chem. Theo. Comput. 2006, 2 (2), 364-382.

26. Galano, A.; Alvarez-Idaboy, J. R., A computational methodology for accurate predictions of rate constants in solution: application to the assessment of primary antioxidant activity. J. Comput. Chem. 2013, 34 (28), 2430-45.

27. Galano, A.; Alvarez-Idaboy, J. R., Kinetics of Radical-Molecule Reactions in Aqueous Solution: A Benchmark Study of the Performance of Density Functional Methods. J. Comput. Chem. 2014, 35.

28. Bartmess, J. E., Thermodynamics of the Electron and the Proton. J. Phys. Chem. 1994, 98, 6420-6424.

29. Marković, Z.; Tošović, J.; Milenković, D.; Marković, S., Revisiting the solvation enthalpies and free energies of the proton and electron in various solvents. Comp. Theo. Chem. 2016, 1077, 11-17.

30. Dzib, E.; Cabellos, J. L.; Ortíz-Chi, F.; Pan, S.; Galano, A.; Merino, G., Eyringpy: A program for computing rate constants in the gas phase and in solution. Int. J. Quant. Chem. 2018, 119 (2), e25686.

31. Okuno, Y., Theoretical investigation of the mechanism of the Baeyer - Villiger reaction in nonpolar solvents. Chem. Eur. J. 1997, 3 (2), 212-218.

32. Benson, S. W., The Foundations of Chemical Kinetics. 1982.

33. Marcus, R. A., Chemical and Electrochemical Electron-transfer Theory. Annu. Rev. Phys. Chem. 1964, 15, 155-196.

34. Collins, F. C.; Kimball, G. E., Diffusioncontrolled reaction rates. 1949, 425-437.

35. Smoluchowski, M. v., Versuch einer mathematischen Theorie der Koagulationskinetik kolloider Lösungen. $Z$. Phys. Chem 1918, 92, 129-168.

36. (a) Einstein, A., Über die von der molekularkinetischen Theorie der Wärme geforderte Bewegung von in ruhenden Flüssigkeiten suspendierten Teilchen. Ann. Phys. 1905, 332 (8), 549-560; (b) Stockes, G. G., Mathematical and Physical Papers. Cambridge: The University Press: New York: The Macmillan Co., , 1905; Vol. V.

37. Jang, Y. H.; Sowers, L. C.; Cagin, T.; III, W. A. G., First Principles Calculation of $\mathrm{pKa}$ Values for 5-Substituted Uracils. J. Phys. Chem. A 2001, 105, 274-280.

38. Shields, G. C.; Seybold, P. G., Computational Approaches for the Prediction of $p K a$ Values. CRC Press, Taylor \& Francis Group: 2014.

39. Jacquemin, D.; Mennucci, B.; Adamo, C., Excited-state calculations with TD-DFT: from benchmarks to simulations in complex environments. Phys. Chem.Chem. Phys. 2011, 13 (38), 16987-16998.

40. Tomasi, J.; Mennucci, B.; Cancès, E., The IEF version of the PCM solvation method: an overview of a new method addressed to study molecular solutes at the QM ab initio level. Journal of Molecular Structure: THEOCHEM 1999, 464 (1), 211-226.

41. Bordwell, F. G.; Algrim, D.; Vanier, N. R., Acidities of Anilines and Toluenes. $J$. Org. Chem. 1977, 42 (10), 1817-1819.

42. Bordwell, F. G.; Algrim, D. J., Acidities of Anilines in Dimethyl Sulfoxide Solution. $J$. Am. Chem. Soc. 1988, 110, 2964-2968.

43. Farmanzadeh, D.; Najafi, M., Novel Trolox derivatives as antioxidant: A DFT 
investigation. J. Serbian Chem. Soc. 2016, 81 (3), 277-290.

44. Ngo, T. C.; Nguyen, T. H.; Dao, D. Q., Radical Scavenging Activity of Natural-

Based Cassaine Diterpenoid Amides and Amines. J. Chem. Inf. Model. 2019, 59 (2), 766-776.

Corresponding author:
45. Dreuw, A.; Head-Gordon, M., Failure of Time-Dependent Density Functional Theory for Long-Range Charge-Transfer Excited States: The Zincbacteriochlorin-Bacteriochlorin and Bacteriochlorophyll-Spheroidene Complexes. Journal of the American Chemical Society 2004, 126 (12), 4007-4016.

\section{Thi Le Anh Nguyen,}

Institute of Research and Development,

Faculty of Natural Sciences,

Duy Tan University, 03 Quang Trung, Da Nang, 550000, Vietnam.

Email: nguyenthileanh@duytan.edu.vn 